\title{
Physicochemical Studies on Indocyanine Green: Molar Lineic Absorbance, pH Tolerance, Activation Energy and Rate of Decay in Various Solvents
}

\author{
By/'O. G. Björnsson, R. Murphy, V. S. Chadwick and S. Björnsson \\ Royal Postgraduate Medical School, Hammersmith Hospital, London, England
}

(Received September 24, 1982/January 19, 1983)

Summary: Physicochemical studies were carried out on the tricarbocyanine dye indocyanine green in biological fluids and organic solvents. The molar lineic absorbance $\varepsilon$ of the compound was highest in organic solvents (methanol, 1.2-propanediol, dimethylformamide) and bile, but lowest in water and duodenal fluid. Indocyanine green remained stable in methanol and bile ( $t_{1 / 2}>1$ year) but was rapidly decomposed to a colourless derivative in duodenal fluid and distilled water $\left(t_{1 / 2} 3.6\right.$ days and 1.4 days, respectively). It was thermostable $\left(120^{\circ} \mathrm{C}\right)$ in methanol and 1.2-propanediol but thermolabile in water and dimethylformamide where the activation energy for the decomposition reaction was low. At ambient temperature $\left(20^{\circ} \mathrm{C}\right)$ indocyanine green was particularly labile at $\mathrm{pH}<5$ and $\mathrm{pH}>11$. The rate of decay of indocyanine green in various solvents indicated that the rate limiting step in the decay process was either a first or zero order reaction.

\section{Physikochemische Untersuchungen an Indocyaningrün:}

Molare lineare Absorbanz, $p H$-Toleranz, Aktivierungsenergie und Zerfallsgeschwindigkeit in verschiedenen Lösungsmitteln

Zusammenfassung: An dem Tricarbocyaninfarbstoff Indocyaningrün wurden physikochemische Untersuchungen in biologischen Flüssigkeiten und organischen Lösungsmitteln durchgeführt. Die molare lineare Absorbanz der Verbindung war am höchsten in organischen Lösungsmitteln (Methanol, 1,2-Propandiol, Dimethylformamid) und Galle, am geringsten in Wasser und Duodenalsaft. Indocyaningrün war in Methanol und Galle stabil ( $\left.t_{1 / 2}>1 \mathrm{Jahr}\right)$, wurde jedoch in Duodenalsaft und destilliertem Wasser sehr schnell zu einem farblosen Abkömmling zersetzt $\left(\mathrm{t}_{1 / 2} 3,6\right.$ bzw. 1,4 Tage). Es wạ thermostabil $\left(120^{\circ} \mathrm{C}\right)$ in Methanol und 1,2Propandiol, jedoch thermolabil in Wasser und Dimethylformamid, in denen die Aktivierungsenergie für die Zersetzungsreaktion niedrig war. Bei Umgebungstemperatur $\left(20^{\circ} \mathrm{C}\right)$ war der Farbstoff besonders labil bei $\mathrm{pH}<5$ und $\mathrm{pH}>11$. Die Zerfallsgeschwindigkeit von Indocyaningrün in verschiedenen Lösungsmitteln zeigte, daß der Zerfallsprozeß eine Reaktionskinetik erster oder nullter Ordnung folgt.

\section{Introduction}

Like most cyanine-dye chromogens indocyanine green (fig. 1) is sensitive to light and unstable on storage in aqueous solutions $(1-5)$. Although there is some information available on this instability in diluted aqueous solutions and during exposure to light $(1,4-8)$, this has not been studied in detail in other solvents and little is known of the effects of temperature on indocyanine green $(1,4)$, and

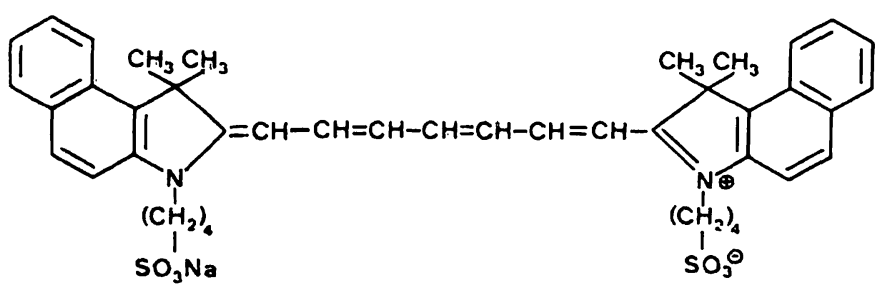

Fig. 1. The structural formula of indocyanine green: anhydro-3, 3, 3', 3'-tetramethyl-1, $1^{\prime}$-(sulfobutyl)-4, 5, 4', 5'-dibenzoindotricarbocyanine hydroxide sodium salt. $M_{\mathrm{r}}=775$. 
Tab. 1. Physicochemical characteristics of indocyanine green in various solvents at constant $\mathrm{pH}$.

\begin{tabular}{|c|c|c|c|c|c|c|c|}
\hline & $\mathrm{pH}$ & $\begin{array}{l}\lambda \max ^{*} \\
(\mathrm{~nm})\end{array}$ & $\begin{array}{l}\varepsilon \\
\left(m^{2} \mathrm{~mol}^{-1}\right)\end{array}$ & $\begin{array}{l}\text { Tinctorial } \\
\text { strength** }\end{array}$ & $k^{* * *}$ & $\begin{array}{l}t_{1 / 2} \\
\text { (days) }\end{array}$ & $\begin{array}{l}\mathrm{Ea} \\
\left(\mathrm{kJ} \mathrm{mol}{ }^{-1}\right)\end{array}$ \\
\hline Human duodenal fluid & 6.3 & 775 & $11.8 \times 10^{3}$ & 1.68 & $1.3 \times 10^{-2}$ & 3.6 & $-t^{t+}$ \\
\hline Single distilled water & 6.3 & 775 & $15.5 \times 10^{3}$ & 1.00 & $2.3 \times 10^{-2}$ & 1.4, & 26.9 \\
\hline Human albumin & 6.1 & 795 & $17.1 \times 10^{3}$ & 1.86 & $1.3 \times 10^{-4 \dagger}$ & $81.0^{\circ}$ & $-{ }^{t \dagger}$ \\
\hline Dimethylformamide & 11.6 & 785 & $21.7 \times 10^{3}$ & 2.12 & $1.8 \times 10^{-3}$ & 49.0 & 43.5 \\
\hline Methanol & 7.3 & 780 & $23.4 \times 10^{3}$ & 2.43 & $5.6 \times 10^{-4}$ & $>1$ year & 15.6 \\
\hline 1.2-Propanediol & 8.1 & 785 & $25.1 \times 10^{3}$ & 2.30 & $2.1 \times 10^{-4 t}$ & $90: 0$ & 17.3 \\
\hline Human bile & 7.4 & 805 & $18.5 \times 10^{3}$ & 1.98 & $3.5 \times 10^{-3}$ & $>1$ year & $-t^{+t}$ \\
\hline
\end{tabular}

* Measured in fresh solutions ( $<15$ min after preparation).

** Calculated as the area under the absorption curves relative to that in distilled water as a solvent.

*** The unit of $\mathrm{k}$ for zero order reaction is $\mathrm{mol} \mathrm{dm}^{-3} \mathrm{~h}^{-1}$, and the unit of $\mathrm{k}$ for first order reaction is $\mathrm{s}^{-1}$. Concentration of indocyanine green $6.45 \mu \mathrm{mol}$.

+ Calculations were based on the period 7-30 days.

${ }^{\text {tt }}$ Not carried out in biological fluids.

changes in $\mathrm{pH}(1,9)$. Because indocyanine green is used as a marker to monitor hepato-biliary excretion into the duodenum (10-12), where $\mathrm{pH}$ and composition of the luminal fluid is variable, we have in the present work studied the effects of storage and changes in $\mathrm{pH}$ on the spectro-photometric absorbance of indocyanine green in various biological fluids. The effects of high temperature on the rate of decay of indocyanine green in several organic solvents were also studied. The organic solvents and temperature were chosen as they might be of value in radiolabelling indocyanine green $(13,14)$.

\section{Materials and Methods}

Reagents used in this work were from British Drug Houses, Poole, England, Sigma London (albumin) and Hynson, Westcott and Dunning Inc., Baltimore, Ltd., 21201, U.S.A. (indocyanine green). Indocyanine green was dissolved in manufacturer's solvent and diluted to the final concentration of $6.45 \mu \mathrm{mol} / \mathrm{l}$ in methanol, 1.2-propanediol, dimethylformamide, single distilled water. human bile (bilirubin concentration $6.2 \mathrm{mmol} /$; total bile salt concentration $12.0 \mathrm{mmol} / \mathrm{/}$ ), human duodenal fluid (fasting. bilirubin free), and $72.5 \mu \mathrm{mol} / \mathrm{h}$ human albumin, respectively. The absorption spectrum of each solution was scanned against the pure solvent $<1 \mathrm{~h}, 12 \mathrm{~h}, 48 \mathrm{~h}, 7$ days, 1 month, 3 months, 6 months and 1 year after the preparation, using a Pye Unicam SP 800 double beam spectrophotometer. Solutions were kept in transparent sealed glass tubes in electric light (300 lux, corresponding to $0.44 \mathrm{Wm}^{-2}$ at its maximum at $550 \mathrm{~nm}$ ) and at temperature $18-20^{\circ} \mathrm{C}$ during the period of storage.Molar lineic absorbance $(\varepsilon)(15)$, tinctorial strength (the integrated absorption intensity) (16), half-lives $\left(t_{1 / 2}\right)$ and rate constants (k) were calculated for indocyanine green in each solvent. Indocyanine green was diluted to the final concentration of $6.45 \mu \mathrm{mol} / /$ in single distilled water, dimethylformamide, methanol and 1.2-propanediol. Aliquots were heated in sealed tubes to $120^{\circ} \mathrm{C}$ for $2 \mathrm{~h}$ in an autoclave, and activation energy for the decay in each solvent calculated, based on absorption spectra before and after heating (14). Indocyanine green was dissolved and diluted to the final concentration of $12 \mu \mathrm{mol} / \mathrm{l}$ in appropriate buffers at $\mathrm{pH} 1.6,5.0,6.4,9.0$ and 12.6 respectively. The absorbance of each solution was scanned against the pure solvent over the wavelength range $600 \mathrm{~nm}$ to $1000 \mathrm{~nm}<1 \mathrm{~h}, 8 \mathrm{~h}, 24 \mathrm{~h}$ and 4 days after the preparation.

\section{Results and Discussion}

Physicochemical characteristics of indocyanine green in various solvents are shown in table 1 . At constant $\mathrm{pH}$ the $\lambda \max$ (the wavelength of the absorption maximum) varied from being lowest in duodenal fluid and distilled water $(775 \mathrm{~nm})$ to being highest in human bile $(805 \mathrm{~nm})$. On the contrary there was no change in $\lambda \max$ in aqueous buffers at different $\mathrm{pH}$ $(775 \mathrm{~nm})$ as shown in table 2 . The molar absorbance of indocyanine green had its minimum value in the duodenal fluid (tab. 1): This is in agreement with previous observations which show that electrolytes decrease the molar lineic absorbance (1). The molar lineic absorbance coefficient was highest in organic solvents.

Table 1 does also show that the tinctorial strength of indocyanine green was not constant, but varied from one solvent to another. This suggests that indocyanine green reacted with the solvents (aggregation effect) (16).

Tab. 2. Physicochemical characteristics of indocyanine green in buffers at various pH's.

\begin{tabular}{rrrlr}
\hline pH & $\begin{array}{l}\lambda_{\max } * \\
(\mathrm{~nm})\end{array}$ & \multicolumn{1}{l}{$\begin{array}{l}\varepsilon \\
\left(\mathrm{m}^{2} \mathrm{~mol}^{-1}\right)\end{array}$} & \multicolumn{1}{l}{$\begin{array}{l}\mathrm{t}_{1 / 2} \\
\text { (hours) }\end{array}$} \\
\hline 12.6 & 775 & $7.60 \times 10^{3}$ & $8.42 \times 10^{-2}$ & 2.0 \\
9.0 & 775 & $12.6 \times 10^{3}$ & $1.31 \times 10^{-2}$ & $>24.0$ \\
6.4 & 775 & $13.2 \times 10^{3}$ & $6.59 \times 10^{-2}$ & 12.8 \\
5.0 & 775 & $11.6 \times 10^{3}$ & $4.66 \times 10^{-2}$ & 3.2 \\
3.2 & 77.5 & $10.7 \times 10^{3}$ & $9.84 \times 10^{-2}$ & 1.2 \\
1.6 & 775 & $5.89 \times 10^{3}$ & $1.23 \times 10^{-1}$ & 2.0 \\
\hline
\end{tabular}

* Measured in fresh solutions ( $<15 \mathrm{~min}$ after preparation).

** Based on the decay during the first $24 \mathrm{~h}$ after preparation. For units of $k$, see legend to table 1 . Conc. of indocyanine green $12.9 \mu \mathrm{mol} / \mathrm{l}$. 
Inspite of the same molecular strength the molar lineic absorbance varied with changes in $\mathrm{pH}$, being lowest in strongly alkaline and acidic solutions and highest in weakly alkaline solutions ( $\mathrm{pH} \mathrm{9).}$

The instability of indocyanine green on storage in diluted aqueous solutions was confirmed in this
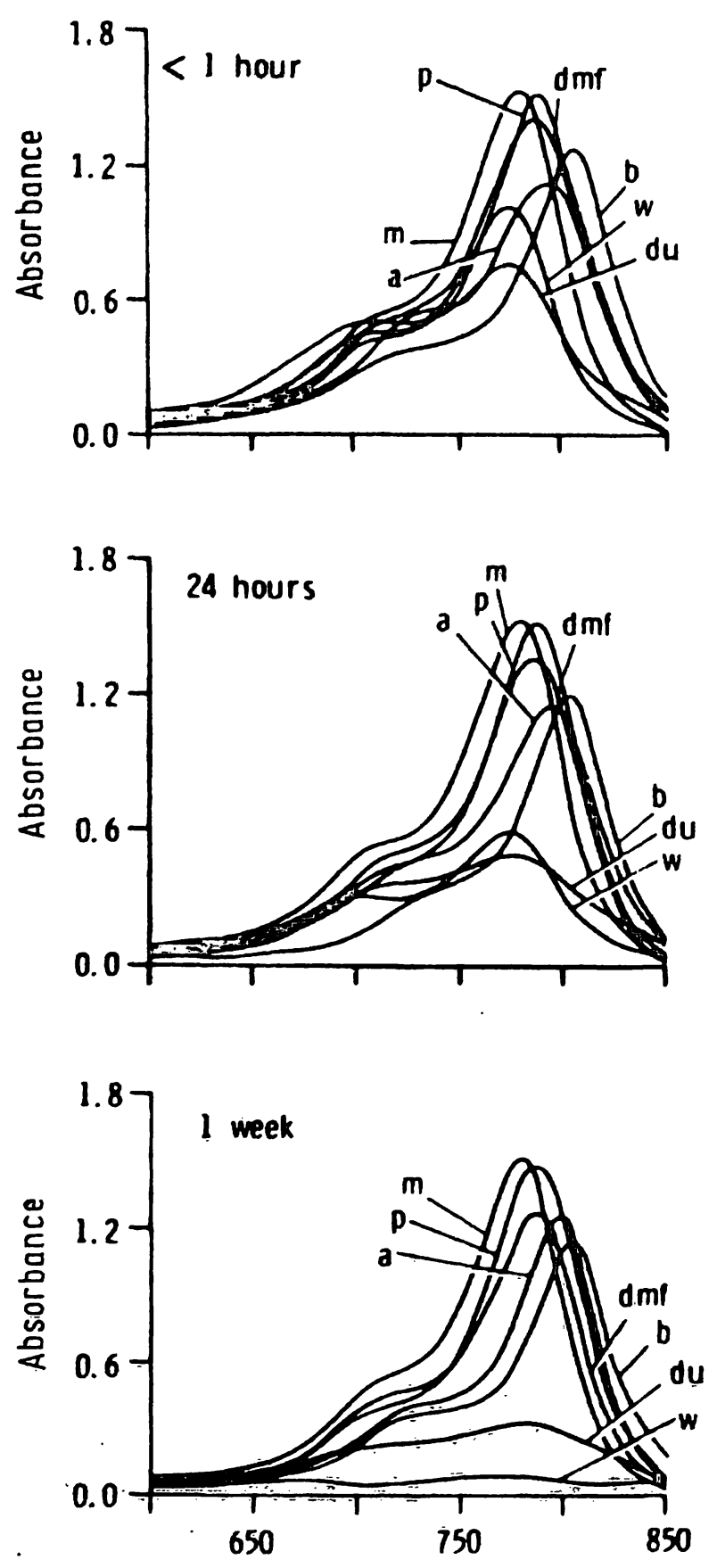

study. A progressive fall in absorbance at $\lambda \max$ was observed in all solutions (figs. 2-3), the absorption curves becoming broad and flattened on storage and the shoulder observed at wavelength $700 \mathrm{~nm}$ to $750 \mathrm{~nm}$ disappeared. The $t_{1 / 2}$ for decay of indocyanine green $(6.45 \mu \mathrm{mol} / \mathrm{l})$ in distilled water was 1.4 days, which is comparable with published figures (4).

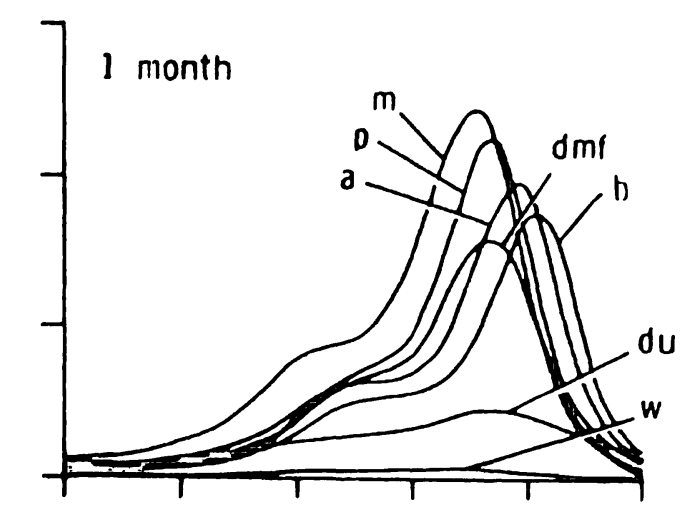

3 months
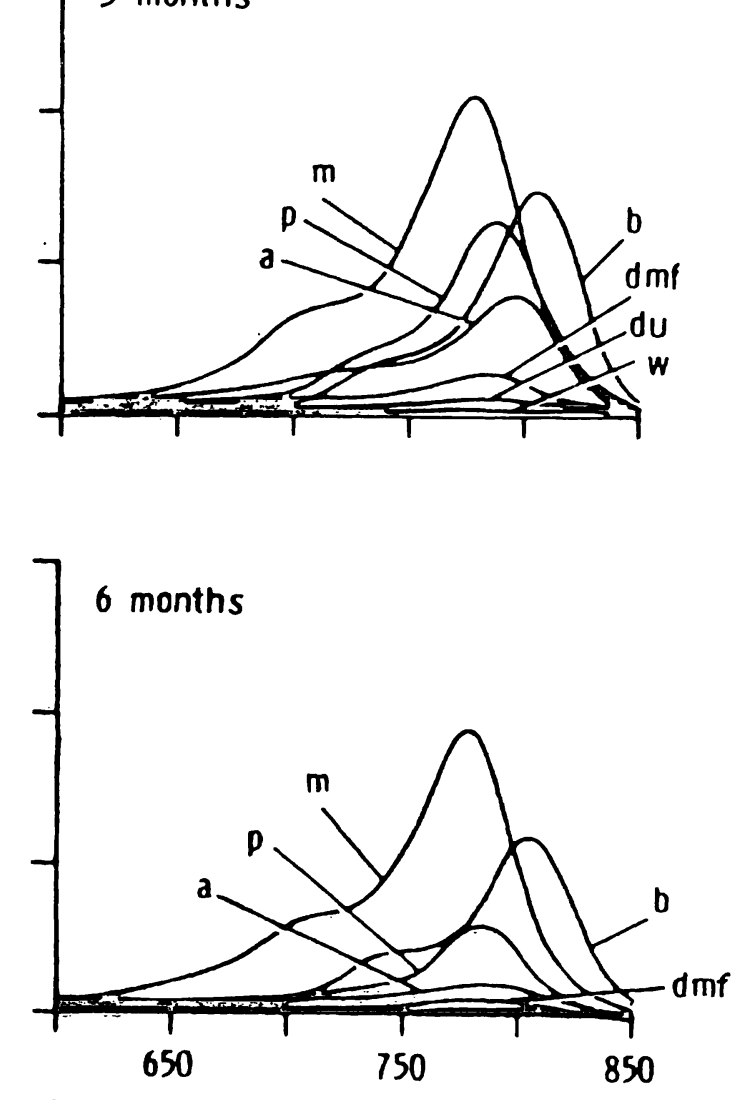

$\lambda[\mathrm{nm}]$

Fig. 2. Absorbance of indocyanine green $(6.45 \mu \mathrm{mol} / 1)$ during 6 months of storage in various solvents drawn as a function of wavelength $(\lambda)$ $(600-850 \mathrm{~nm})$

$\mathrm{a}=72.5 \mu \mathrm{mol} / 1$ human albumin;

$\mathrm{m}=$ methanol;

$p=1.2$-propanediol;

$\mathrm{dmf}=$ dimethylformamide;

b = humanan bile;

$\mathbf{w}=$ distilled water;

$\mathrm{du}=$ human duọdenal fluid free of bile (fasting). 


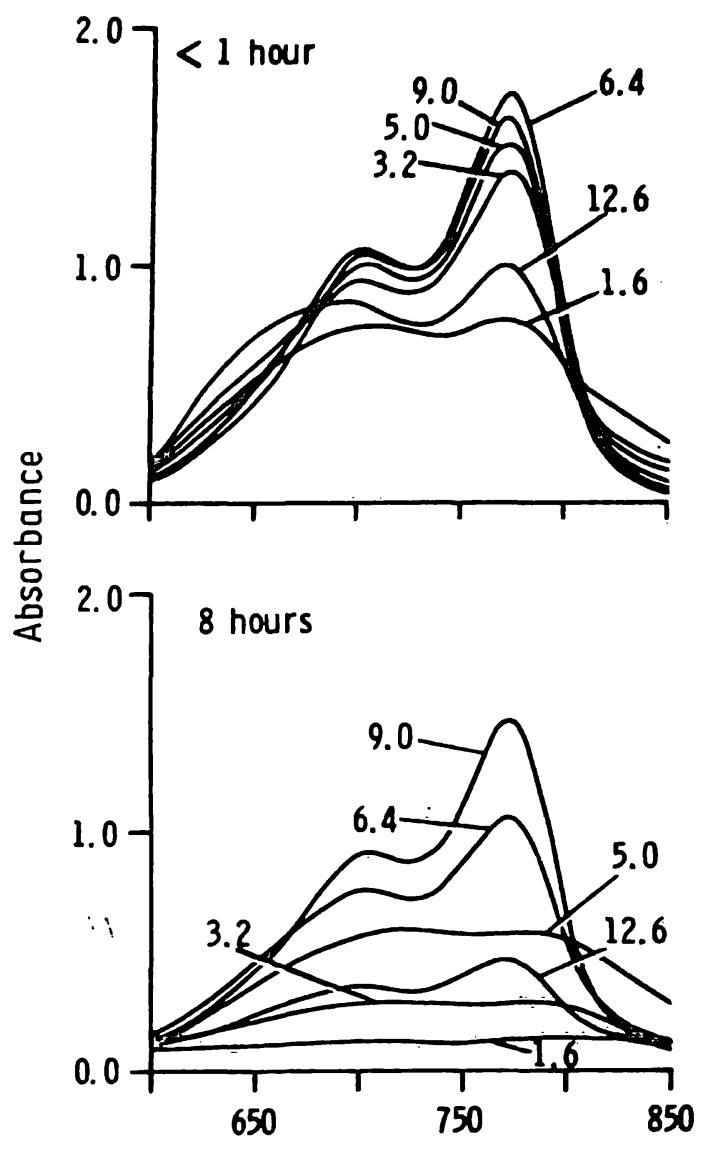

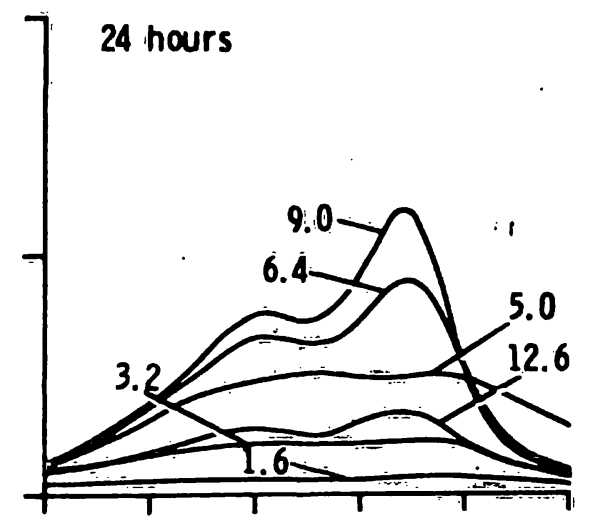

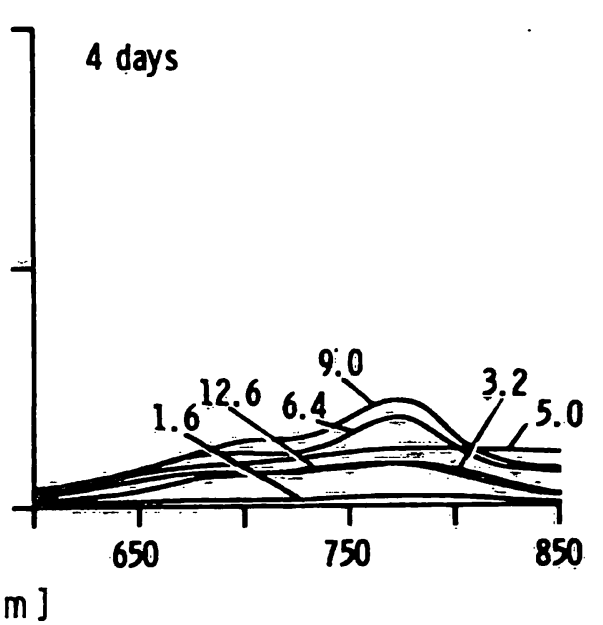

Fig. 3. Absorbance of indocyanine green $(12.9 \mu \mathrm{mol} / \mathrm{l})$ at $\mathrm{pH} 12.6,9.0,6.4,5.0,3.2$ and 1.6, drawn as a function of wavelength $(\lambda)$ $(600-850 \mathrm{~nm})<1 \mathrm{~h}, 8 \mathrm{~h}, 24 \mathrm{~h}$ and 4 days after preparation.

In duodenal fluid the $t_{1 / 2}$ was estimated as being 3.6 days, which was greater than expected, since electrolytes have been found to promote indocyanine green degradation $(4,5)$; the protein content of the duodenal fluid may, however, have opposed the ionic effect (4). Indocyanine green was relatively stable in dimethylformamide, human albumin and 1.2-propanediol, but most stable in methanol and bile $\left(t_{1 / 2}>\right.$ 1 year). The stability in bile was found not to be due to protein, as there was no change in stability of indocyanine green in protein precipitated bile. The decay of indocyanine green was exponential in biological fluids (apart from human albumin), indicating that the decay was of first order reaction. In human albumin an increase in absorbance was observed during the first 7 days of storage (aggregation), after which indocyanine green decayed in a linear fashion, similar to that observed in organic solvents (zero order reaction). In aqueous buffers at various $\mathrm{pH}$, $\mathrm{t}_{1 / 2}$ varied from 1 to $2 \mathrm{~h}$ in strongly acidic ( $\mathrm{pH} 1.6$ to 3.2) and alkaline ( $\mathrm{pH} 12.6$ ) solutions (tab. 2) to $24 \mathrm{~h}$ at $\mathrm{pH}$ 9.0. The effect of $\mathrm{pH}$ on the absorbance of indocyanine green may be explained by the fact that many cationic dyes react with water at high $\mathrm{pH}$ values to form initially a "carbinol" type base, which is colourless. This compound may either degrade further to colourless compounds, or it can regenerate the original cationic dye on acidification. Similarly, the more hypsochromic colour in acid may result from protonation which gives dicationic species.

Indocyanine green seems to be relatively stable at the $\mathrm{pH}$ range which is expected in the intestinal lumen ( $\mathrm{pH}$ 6.0-8.0). The decay curves in aqueous buffers were exponential.

It was possible to calculate the decay rate constant (k) for indocyanine green in various solutions and this correlated with $t_{1 / 2}$. Figure 4 shows that the decomposition of indocyanine green when heated at $120^{\circ} \mathrm{C}$ for $2 \mathrm{~h}$ was minimal in methanol and 1.2 -propanediol, in contrast to almost a complete decay in dimethylformamide and distilled water. Based on this, the activation energy (Ea) of the decomposition reaction of indocyanine green in dimethylformamide and distilled water was calculated. It was found to be low; which suggested that there was a little energy barrier to be overcome for the decomposition reac= tion to occur in these solvents, and in fact this was lower than the thermal energy available at room temperature. i 

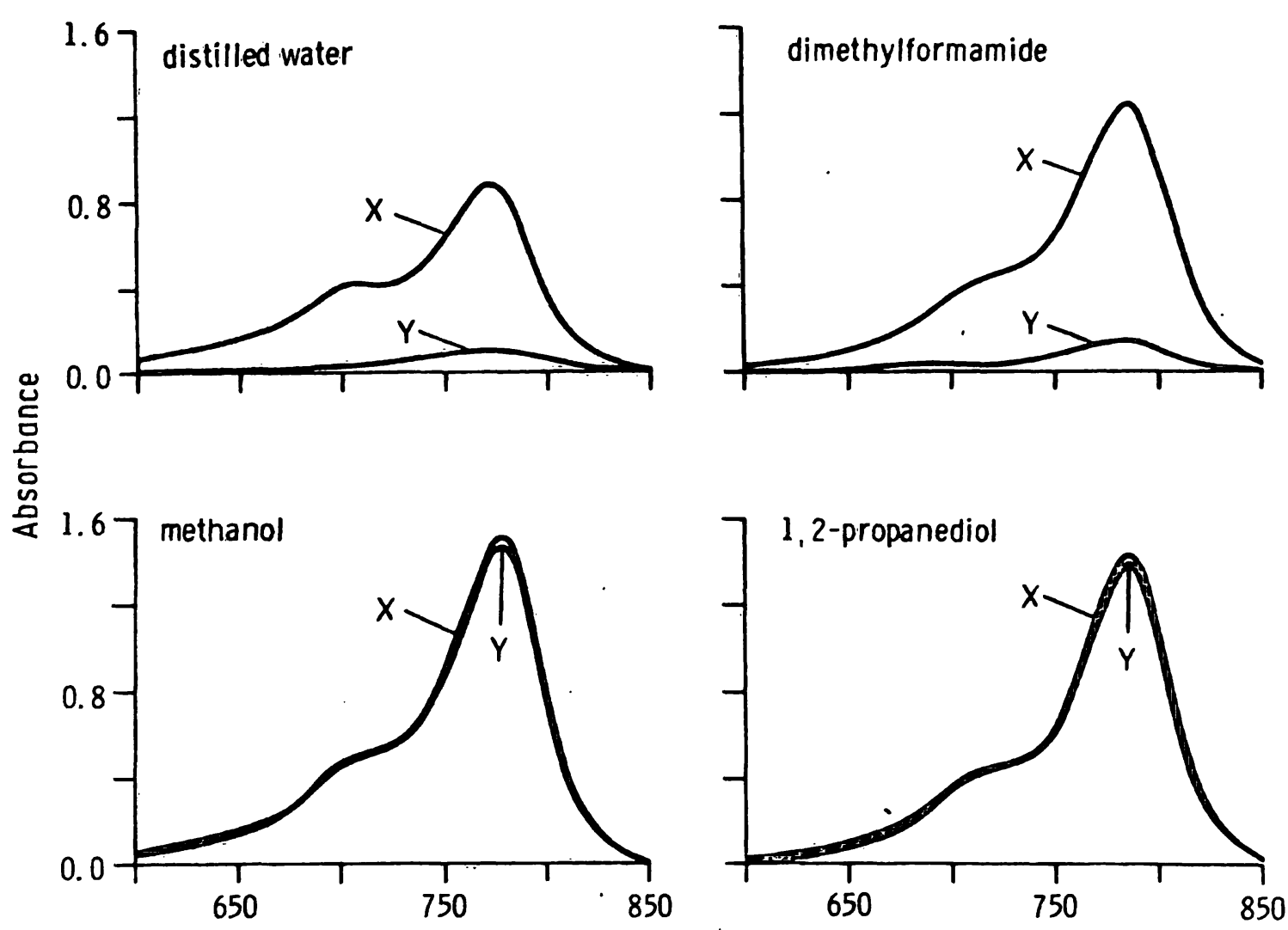

$\lambda[\mathrm{nm}]$

Fig. 4. Absorbance of indocyanine green $(6.45 \mu \mathrm{mol} / \mathrm{l})$ before $(\mathrm{x})$ and after $(\mathrm{y})$ heating $\left(120^{\circ} \mathrm{C}\right.$ for $\left.2 \mathrm{~h}\right)$ in distilled water, dimethylformamide, methanol and 1.2-propanediol. drawn as a function of wavelength $(\lambda)(600-850 \mathrm{~nm})$.

Activation energy measured at different temperatures is usually measured over several half-lives for the reaction; thus the stability of indocyanine green in methanol and propanediol (where $t_{1 / 2}$ is very low) precludes measurement of the activation energy in these solvents. It may be that in the more polar solvents (water and dimethylformamide) the relatively hydrophobic indocyanine green molecule adopts a tight, folded configuration which allows intramolecular re-arrangement of the molecule. In the more hydrophobic solvents (methanol and 1.2-propanediol) such a configuration may be disrupted by solvation and thus prevent the intramolecular re-arrangements that may be involved in the decay of indocyanine green. An intramolecular reaction mechanism seems likely from the kinetic data, which imply a unimolecular reaction governed by either zero or first order kinetics.

The results presented indicate that indocyanine green is not suitable for tritium labelling in aqueous or dimethylformamide media at high temperature or in acidic solutions even at ambient temperature (13).

\section{Acknowledgements}

The authors wish to thank Dr. P. N. Maton and Dr. N. B. Myant, Hammersmith Hospital, for helpful discussions, and Mrs. Patricia Weller for expert secretarial assistance. This work was supported by a Grant to O.G.B. from Vísindasjódur Íslands, Iceland.

\section{References}

1. Fox, I. J. \& Wood, E. H. (1960) Proc. Staff Meet. Mayo Clin. $35,732-744$.

2. Michie, D. D., Goldsmith, R. S. \& Mason, A. D. (1962) Proc. Soc. Exp. Biol. Med. 111, 540-543.

3. Sutterer, W. F., Hardin, S. E., Benson, R. W., Krovetz, L. J. \& Schiebler, G. L. (1966). Am. Heart J. 72, 345-350.

4. Gathje, J., Steuer, R. R. \& Nicholes, K. R. K. (1970) J. Appl. Physiol. 29, 181-185.

5. Landsman. M. L. J., Kwant, G., Mook. G. A. \& Zijlstra, W. G. (1976) J. Appl. Physiol. 40. 575-583.

6. Usui. T. \& Kawamoto, H. (1971) Clin. Chim. Acta 31, 477478. 
7. Porstmann, W. \& Banaschak, H. (1965) Dtsch. Gesundheitswes. 20, 889-893.

8. Baker. K. J. (1966) Proc. Soc. Exp. Biol. Med. 122. 957963.

9. Jones Owen, M. V. (1973) Clin. Biochem. 6. 132-135.

10. van Berge Henegouwen, G. P. \& Hofmann, A. F. (1978) Gastroenterology 75, 879-885.

11. Björnsson, O. G., Adrian, T. E., Dawson, J., McCloy, R. F., Greenberg, G. R., Bloom. S. R. \& Chadwick, V. S. (1979) Eur. J. Clin. Invest. 9, 293-300.

12. Björnsson. O. G.. Maton, P. N., Fletcher, D. R. \& Chadwick. V. S. (1982) Eur. J. Clin. Invest. 12, 97-105.
13. Radiochemicals (1980) The Radiochemical Centre, Amersham, England, 128-131.

14. Ansari, A. N., Atkins, H. L., Lambrecht, R. M., Redvanly, C. S. \& Wolf, A. P. (1975) In: Dynamic Studies with Radioisotopes in Medicine, Vol. I., IAEA-SM-185/61, 111-123.

15. Willard, H. H., Merritt, L. L., Dean. J. A. \& Settle, F. A. (1981) In: Instrumental Methods of Analysis, 6th Ed., D. Van Nostrand Company, New York, 66-70.

16. Griffiths, J. (1976) In: Colour and Constitution of Organic Molecules, Academic Press, New York, 64-67.

17. Barrow, G. M. (1961) In: Physical Chemistry, McGraw-Hill, New York, 327.
'Olafur Grimur Björnsson, M.D., Ph. D. MRC Metabolism Unit

Cyclotron Building, 4th Floor

Hammersmith Hospital

Du Cane Road

London, W12 OHS

England 